<総 説 $>$

（受理: 平成 22 年 11 月 4 日）

\title{
木質バイオマス由来エポキシ樹脂システム開発の進歩（下） 一木材ベースエポキシ樹脂システムの開発動向一 Progress in Development of Epoxy Resin Systems Based on Wood Biomass, Part II - Development Trend of Epoxy Resin Systems Based on Native Wood-
}

\section{2 木材ベースエポキシ樹脂システム}

木材自体に何らかの処理を施した後にエポキシ化等の操 作をすることで，エポキシ樹脂システムとして活用するこ とを目指した開発手法については，表 4 にまとめてある。 木材をエポキシ樹脂システムとして利用する手法には大別 して，(1)木材に高温水蒸気，酸，アルコール，フェノール， オゾンなどを用い物理的・化学的な一次処理をした後，さ らにエポキシ化などの二次処理する方法と，(2)木材からエ ポキシ樹脂の原料となる物質（フェノール誘導体など）を 化学的または生化学的に精製して得た後，エポキシ樹脂を 得る方法, がある。また, リグニンベースの場合と同様に, 木材ベースの場合についても，その变性法，架橋法につい て模式図を表 5 と表 6 に示してある。(2)の手法によるエポ キシ樹脂は精製により得られるため，特性的に優れ適用範 井が広いと思われるが，(1)の手法によるエポキシ樹脂シス テムは精製を必要としない場合が多く，比較的安価なむの になると期待される。したがって，適用される用途ごとに ケース・バイ・ケースで，両者の棲み分けも可能になると 思われる。以下，各木材べースエポキシ樹脂システムにつ き，簡単に解説を加えてみたい。

3.2.1 木材 (シラカンバ材) 蒸煮処理 $\left(180^{\circ} \mathrm{C}\right)$ 後, 温水抽出した残渣をメタノール抽出しリグニンを分離。さ

\footnotetext{
*(㑣) 有沢製作所 電子材料技術部

新潟県上越市中田原 1 番地 ○ 943-8610

Electronics Material Technology Development Dept., Arisawa Manufacturing Co., Ltd.

1-Nakadahara, Joetsu, Niigata, 943-8610, Japan
}

((上)ーリグニンベースエポキシ樹脂システムの開発動向ーは Vol. 47, No.6 (2011)（23）[242] に掲载)
小池常夫*

Tsuneo KOIKE
らにオゾン処理しムコン酸残基を有するオゾン酸化リグニ ンを得る。このオゾン酸化リグニンを，ビスフェノール $\mathrm{A}$ 型エポキシ樹脂に熱溶解し， $120^{\circ} \mathrm{C} て ゙$ 加熱してカルボキ シル基とエポキシ基を反応させることで，プレリアクト型 のオゾン酸化リグニンノエポキシ樹脂を得る方法（表 4$\mathrm{H}$, 表 5-H)。

このリグニンエポキシ樹脂の DETA やへキサメチレン ジアミン（HMDA）などの脂肪族ポリアミン類による硬 化物は, 幅広い粘弾性分散をもち一種の IPN を形成して いると解釈されている。そして，オソン酸化リグニンの添 加量が多いほど分散の幅が広くなり， $T_{g}$ も高温側にシフ トする傾向が確認されている32)。また，硬化剤として使用 するポリアミンを選択すれば， $T_{\mathrm{g}}$ は低温域から高温域ま で任意に設計できるので，接着剂や成型品への応用が可能 と考えられている。

3.2 .2 木材（カラマッ，杉など）を，水蒸気爆砕装置 （最高温度 : $275^{\circ} \mathrm{C}$, 最高压力: $6.0 \mathrm{MPa}$ ）を用い高圧水蒸 気により分解する。得られた固体混合物から水溶性成分を

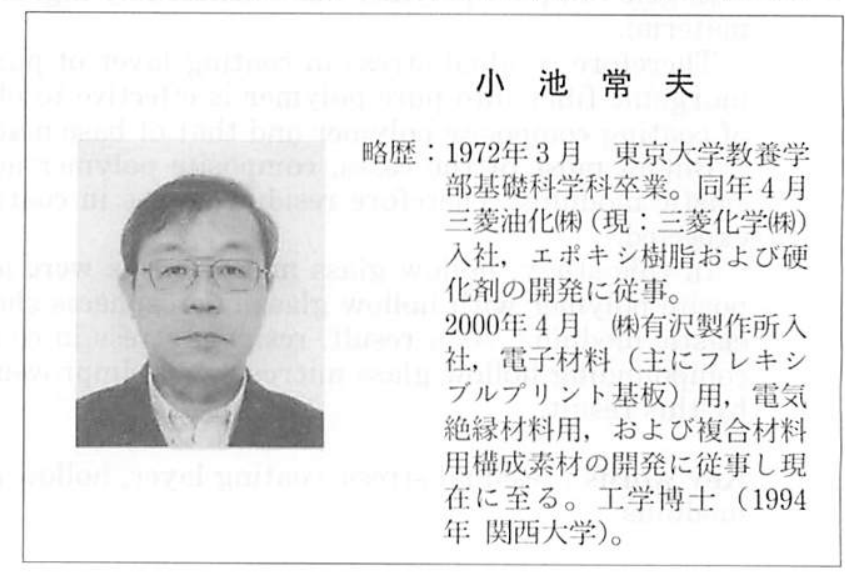


表 4 木材処理によるリグニン成分含有エポキシ樹脂システム

\begin{tabular}{|c|c|c|c|c|c|c|c|c|c|c|}
\hline \multirow{3}{*}{\multicolumn{2}{|c|}{$\begin{array}{l}\text { 研究者グルーブ } \\
\text { (大学・公的機関) }\end{array}$}} & \multirow{4}{*}{$\begin{array}{c}\text { 木筫原料 } \\
\begin{array}{c}\text { 木材 } \\
\text { (シラカバ) }\end{array}\end{array}$} & \multicolumn{5}{|c|}{ 木質原料の処理方法 } & \multirow{4}{*}{$\begin{array}{l}\text { 架撟剂の例 } \\
\begin{array}{l}\text { 诺肪族アミン } \\
\text { (in アセトン) }\end{array}\end{array}$} & \multirow{4}{*}{ 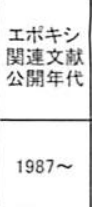 } & \multirow{4}{*}{\begin{tabular}{|c|} 
文苚 \\
32
\end{tabular}} \\
\hline & & & \multicolumn{3}{|c|}{ 一次処理 } & \multirow{3}{*}{$\begin{array}{c}\text { 二次処理 } \\
\text { 処理剛 } \\
\begin{array}{l}\text { エボキジ㯕脂 } \\
\text { (プレリアト) }\end{array}\end{array}$} & \multirow{3}{*}{$\begin{array}{c}\text { 付与官能基 } \\
\text { エボキシ }\end{array}$} & & & \\
\hline & & & 処理绪 & 処理内容(条件等) & 生成物 & & & & & \\
\hline $\mathrm{H}$ & 東京大 & & $\begin{array}{l}\cdot \text { 水蒸気 } \\
\cdot \cdot \text { 水、多ノール } \\
\cdot \text { ·3オソン/酸素 }\end{array}$ & 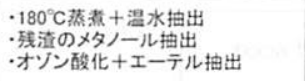 & $\begin{array}{l}\text { オゾン酸化 } \\
\text { リグニン }\end{array}$ & & & & & \\
\hline 1 & $\begin{array}{l}\text { 金沢大 } \\
\text { 德鳥大 } \\
\text { 棤浜国大 }\end{array}$ & $\begin{array}{c}\text { 木材 } \\
\text { (カラマツ、スギ) }\end{array}$ & $\begin{array}{l}\cdot \cdot \text { 水蒸気 } \\
\cdot \text { 水、メタノール }\end{array}$ & 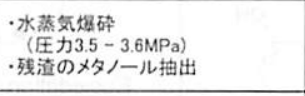 & $\begin{array}{l}\text { メターール可溶 } \\
\text { リグニン }\end{array}$ & $\begin{array}{l}\text { エビクロルヒドリン } \\
\text { 10s NaOH } \\
\text { TMAH }^{b 3}\end{array}$ & エポキシ & 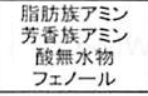 & 1998 & $33 \sim 35$ \\
\hline J & $\begin{array}{l}\text { 筑波大 } \\
\text { 森林総研 }\end{array}$ & $\begin{array}{l}\text { 木村 (スギ) or } \\
\text { オソ゚ン処理木材 }\end{array}$ & $\begin{array}{l}\cdot P E G^{a)} / \text { /゙リセリン } \\
\text { ·硫酸 }\end{array}$ & ·木材の液状化 $\left(150,170^{\circ} \mathrm{C}\right)$ & 液状木材 & - & 水酸器 & $\begin{array}{l}\text { エボキシ樹脂 } \\
\text { 脂肪族アシジ } \\
\text { or クエン酸 }\end{array}$ & $2000 \sim$ & $36 \sim 40$ \\
\hline K & \multirow{2}{*}{ 兵庫県立大 } & \multirow{2}{*}{$\begin{array}{c}\text { 木材 } \\
\text { (トウヒ) }\end{array}$} & $\begin{array}{l}\text { •レゾルシノール } \\
\text { ·硫酸 }\end{array}$ & $\begin{array}{l}\text { ·木材の液状化・フェノール化 } \\
\left(250^{\circ} \mathrm{C}\right)\end{array}$ & $\begin{array}{l}\text { フェノール化 } \\
\text { 液状木材 }\end{array}$ & $\begin{array}{c}\text { エピクロルヒドリン } \\
50 \mathrm{~s} \mathrm{NaOH}\end{array}$ & エボキシ & 芳香㨴アミン & $2005 \sim$ & $41 \sim 44$ \\
\hline L & & & $\begin{array}{l}\cdot P E G^{21} / \text { /゙リセリン } \\
\text { ·硫酸 } \\
\cdot \text { ·ピクロルヒドリン }\end{array}$ & $\begin{array}{l}\cdot \text { 㦿材の液状化·アルコール化 } \\
\left(140^{\circ} \mathrm{C}\right) \\
\cdot \text { ·ェール性OHのアルコール変换 }\end{array}$ & $\begin{array}{l}\text { アルコール化 } \\
\text { 液状木材 } \\
\text { (プリアクト) }\end{array}$ & $\begin{array}{l}\text { エピクロルヒドリン } \\
\text { 相間移動触媒c } \\
\text { 固形 } \mathrm{NaOH}\end{array}$ & エポキシ & 脂肪族アミン & $2009 \sim$ & 45,46 \\
\hline M & $\begin{array}{c}\text { 三垂大 } \\
\text { 大阪市工研 }\end{array}$ & & ·p-クレゾール/溶媒 & 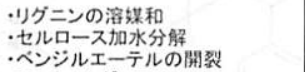 & 4 & $\begin{array}{c}\text { エピクロルヒドリン } \\
\text { 20s } \mathrm{NaOH}\end{array}$ & エポキシ & イミダゾール & $2006 \sim$ & 49. 50 \\
\hline $\mathrm{N}$ & $\begin{array}{c}\text { 三重大 } \\
\text { 横浜国大 }\end{array}$ & (ヒノキ、ノナ击) & - $72 \%$ 研酸 & 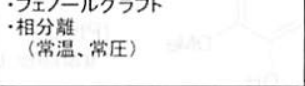 & & $\begin{array}{l}\text { エピクロルヒドリン } \\
\text { 相間移動触媒 }^{\text {d }} \\
508 \mathrm{NaOH}\end{array}$ & エポキシ & リグノフェノール & $2009 \sim$ & 51,52 \\
\hline 0 & $\begin{array}{l}\text { 東京㷧工大 } \\
\text { 長用技科大 } \\
\text { 森林粉研 }\end{array}$ & 木材 & 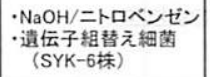 & $\begin{array}{l}\cdot \text { 条林のアルカリ分触 } \\
\cdot \cdot \text { 低分子リグニン物物分解 } \\
\cdot \text { 抽出·再結晶 }\end{array}$ & $\begin{array}{c}P D C \\
\text { (2-ビロン-4,6- } \\
\text { ジカルボン䂺) }\end{array}$ & $\begin{array}{l}\text { グリシドール } \\
\text { or } \\
\text { アリルアルコール }\end{array}$ & エポキシ & 酸與水物 & $2009 \sim$ & $53 \sim 64$ \\
\hline
\end{tabular}

a）ポリエチレングリコール，b）水酸化テトラメチルアンモニウム， c) 硫酸水素テトラプチルアンモニウム，d）テトラブチルアンモニ ウムプロミド

表 5 木材変性法および架橋法模式図 (1)

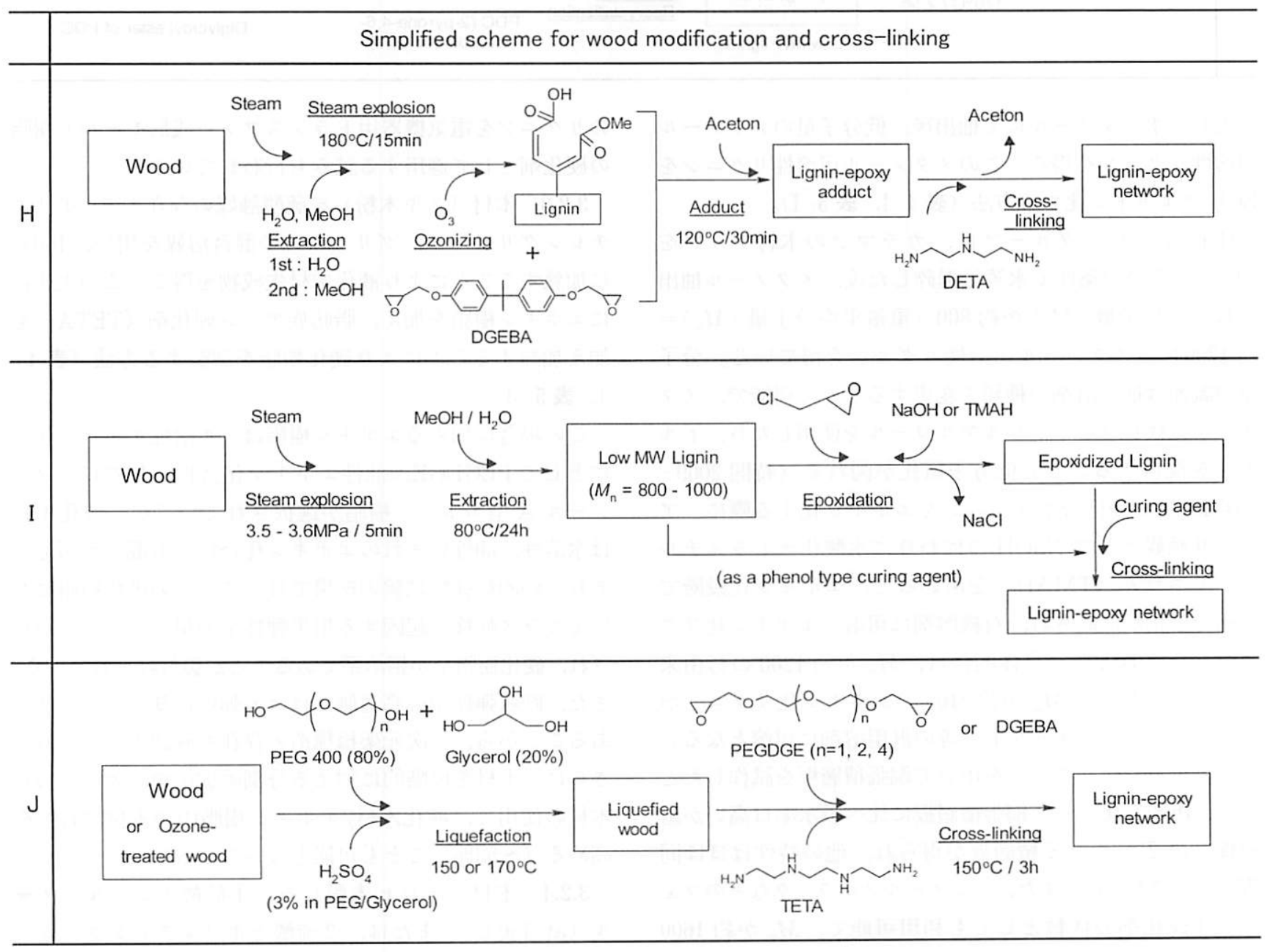


表 6 木材変性法および架橋法模式図 (2)

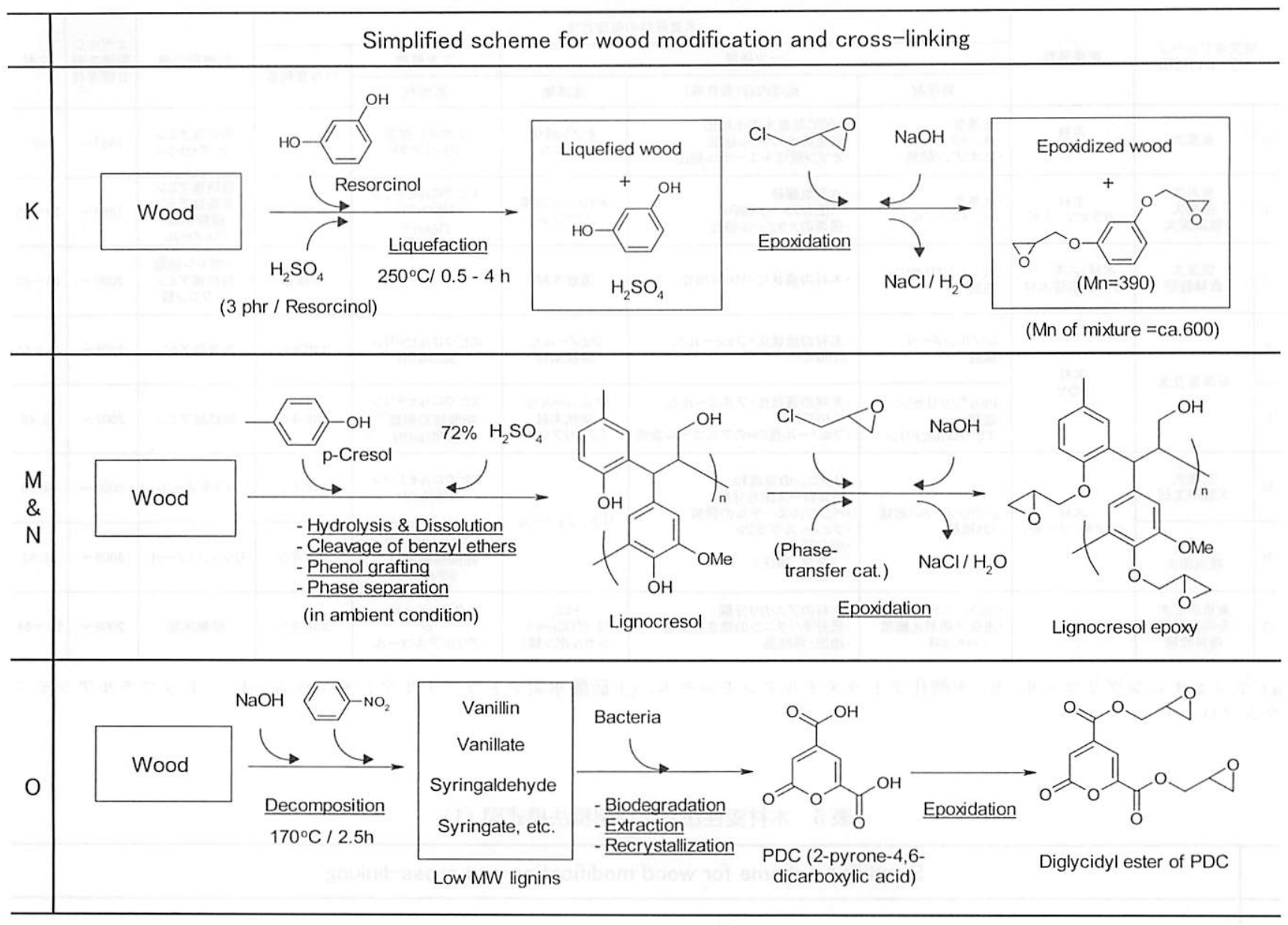

除去し含水メタノールにて抽出後, 低分子量のメ夕ノール 可溶性リグニンを得る。このメタノール可溶性リグニンを $\mathrm{ECH}$ でエポキシ化する方法（表 4-I，表 5-I）。

中村ら ${ }^{33,34)}$ のグループは，カラマッの木材チップを $3.6 \mathrm{MPa} / 5$ 分の条件で水蒸気爆砕した後, メ夕ノール抽出 し数平均分子量 $\left(M_{\mathrm{n}}\right)$ が約 800 (重量平均分子量 $\left(M_{\mathrm{w}}\right)=$ 約 1200）のメタノール可溶性リグニンを得ている。分子 量の調節は抽出溶剂の種類を变更することで可能で, メ夕 ノールの代わりにイソピルアルコールを使用したり, トル エンを混合することで低分子量化が図れる（特開 2009263549)。この低分子リグニンをエポキシ化する際に, ア ルカリ触媒として $\mathrm{NaOH}$ の代わりに水酸化テトラメチル アンモニウム (TMAH) を用いると, エポキシ化段階で の高分子化が抑制され，有機溶剤に可溶なエポキシ化リグ ニンが得られる ${ }^{35)}$ 。具体的には, $M_{\mathrm{w}}$ が約 1200 の杉由来 のリグニンからは $M_{\mathrm{w}}$ が約 2100 のエポキシ化リグニンが 得られ, メチルェチルケトン等の汎用溶剤に可溶となる。 このエポキシ化リグニンを用いて銅張積層板を試作したと ころ, 市販石化ベース銅張積層板に比べ吸水率は高いが耐 熱性（高 $T_{\mathrm{g}}$ ）のある積層板が得られ，他の特性はほぼ同 等のあのであった。また, フェノールノボラックなどのフェ ノール硬化剂の代替としても利用可能で， $M_{\mathrm{w}}$ が約 1600
のリグニンを電気機器用トランスファー成形モールド樹脂 の硬化剂として適用する試みも行われている35)。

3.2 .3 木材（スギ木粉）を硫酸触媒の存在下で, ポリエ チレングリコール，グリセリンの混合溶媒を用い， $150^{\circ} \mathrm{C}$ に加熱することにより液化木材生成物を得る。この生成物 にエポキシ樹脂を加え, 脂肪族アミン硬化剂 (TETA) を 加え加熱することにより硬化樹脂を調製する方法（表 4-

\section{J, 表 $5-\mathrm{J})$ 。}

この場合に加えるエポキシ樹脂は, 水溶性エポキシ化合 物としてPEGDGE, 油性エポキシ化合物としてビスフェ ノール A 型エポキシ樹脂が選択されているが, 液化木材 は水溶性, 油性いずれのエポキシ化合物とも混合が可能で あり, 動的粘弾性試験の結果では, すべての硬化樹脂にお いてガラス転移に起因する損失弾性率の単一ピークが観察 され, 硬化樹脂系が相溶系であることが裹付けられている。 また, 貯蔵弾性率の高温側にはゴム弾性に基づく平坦部が あることから，三次元架橋構造の存在も確認されている。 さらに, 木材を段階的に加える分割添加法や，オゾン酸化 木材の使用で, 液化木材/エポキシ樹脂中の木材含有率を 高める ( 53\%) ことも可能となっている ${ }^{36 \sim 40)}$ 。

3.2.4 木材（トウヒ木粉）を, (1)硫酸とレゾルシノー ル (at $\left.150^{\circ} \mathrm{C}\right)$ ，または, (2)硫酸とポリエチレングリコー 
ル/グリセリン混合溶媒（at $140^{\circ} \mathrm{C}$ ), で $2 \sim 4 h$ 処理（加 圧下）して液状木材混合物を得る。得られた液状木材は分 離・精製せずに，液状木材中のフェノール性水酸基やアル コール性水酸基を ECH でェポキシ化し，木材ベースエポ キシ樹脂を得る方法 (表 $4-\mathrm{K}, \mathrm{L}$ ，表 6-K)。

この方法は, 岸らのグループにより開発されたもので, 上記の(1)と(2)の方法以外に硫酸を用いずに水とレゾルシノール のみで液状化する方法す可能であるが, その場合は $250^{\circ} \mathrm{C}$ での処理が必要となる。これらレゾルシノールや多価アル コール（ポリエチレングリコール，グリセリン）などの溶 媒を木材の液状化に用いる方法（加溶媒分解反応）では, 反応時間依存性はあるものの検討されたシステムではほと んどが木材と結合していると考えられている ${ }^{41 ~ 43) 。 ~}$

レゾルシノールを用いる上記(1)の手法による木材ベース エポキシ樹脂は芳香族アミンによる硬化物性が評価されて いる。硬化物の動的粘弾性測定によるとビスフェノール $\mathrm{A}$ 型エポキシ樹脂に比較し $T_{g}$ がやや低く, 分子量分布が 広いことによる広い転移領域を示すが, ガラス状領域の貯 蔵弾性率はほぼ同等で, ゴム状領域の眝蔵弾性率はやや高 いという結果が得られている。また，曲げ特性や接着特性 むビスフェノール A 型エポキシ樹脂に匹敵する特性が得 られ, 十分な架橋構造を有していると推定される。さらに, 植物系織維(亜麻繊維)を強化材とする天然䄉維強化複合材 料を調整したところ, 亜麻䋐維への木材エポキシ樹脂の接 着性は市販エポキシ樹脂より優れることが判明している (特開 2006-63271) ${ }^{44)}$ 。

(1)の手法によるレゾルシノールでの木材液状化の場合は, 木材の再縮合による残渣（不溶成分）が形成される問題が あったが，(2)の手法の多価アルコールによる液状化では，
グリセリンを併用することで木材同士の再縮合を防ぐこと が可能となっている。一方, 多価アルコール使用の場合に は, エポキシ化処理の際に木材中の反応性の高いフェノー ル性水酸基によるゲル化が障害となっていた。しかしこ の問題は, エポキシ化前に $\mathrm{ECH}$ を加えプレリアクトし, フェノール性水酸基をアルコール性水酸基に変換しゲル化を 抑える新規な合成ルートをとることで解決できている ${ }^{45.46)}$ 。 このフェノール類を用いない手法は, フェノール類で問題 視される安全衛生面の改善以外に, 硬化物の良好なダンピ ング特性を利用した用途む視野に入れた特許として出願さ れている（特開 2009-41010）。

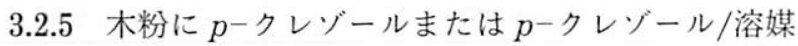
（アセトンなど）を含浸し，木材のリグニン成分を $p-ク$ レゾールにより溶媒和させた後, $72 \%$ 濃硫酸を加え木材の

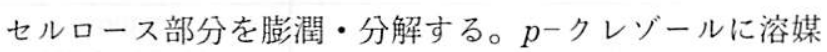

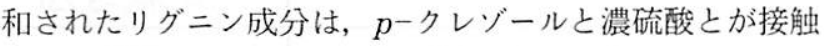
する界面においてのみ酸と接触し，この際生じた高反応サ イトの $\alpha$ 位が $p$-クレゾールにより攻撃されて, リグノク レゾールが生成される（図 6 の模式図参照）。そして, 水 相（セルロース由来成分）と有機相（リグノクレゾールを 含む成分）に分離後, 抽出・精製することでリグノクレゾー ルが得られる。このリグノクレゾールを $\mathrm{ECH}$ でエポキシ 化して，エポキシ化リグノクレゾール樹脂を得る（表 4$\mathrm{M}, \mathrm{N}$, 表 6-M\&N)。

このリグノフェノールの製造法は「相分離変換法」と呼 ばれ, 舩岡ら ${ }^{47,48)}$ のグループにより開発されたあので, 得られたリグノフェノールはリグニンにフェノール誘導体 が結合した線状の分子構造を有し, 天然リグニンの基本結 合系を高度に保持している。この製法で $p$-クレゾールを

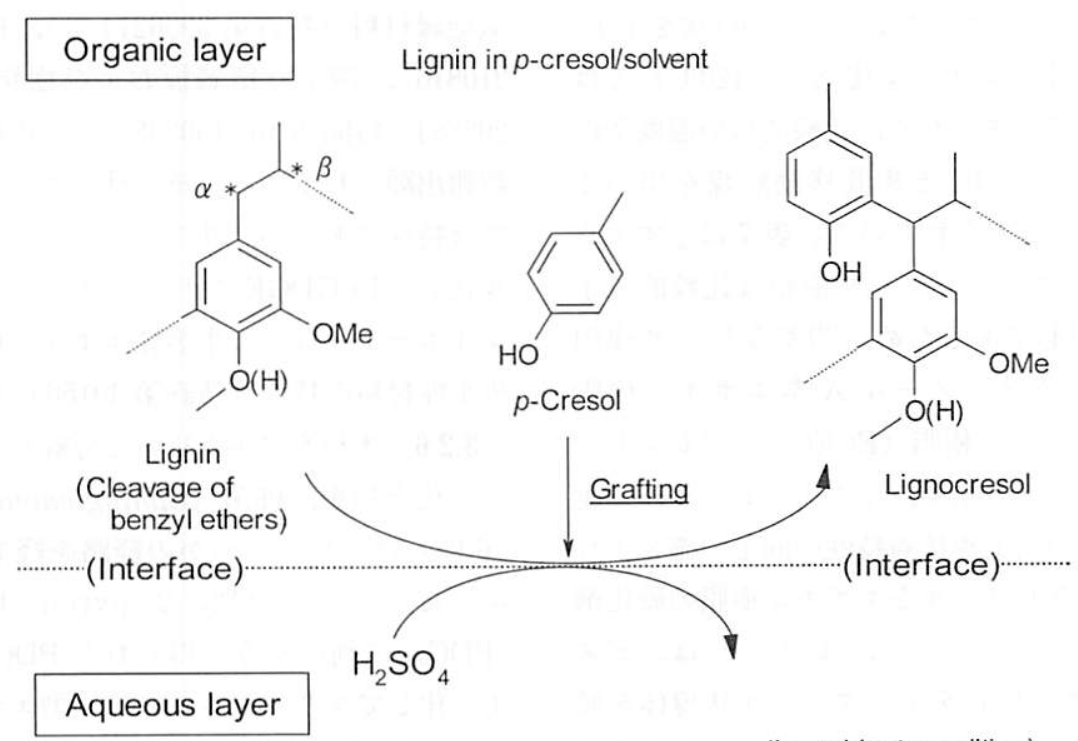

Cellulose/hemicellulose

(in ambient condition) in $72 \%$ sulfuric acid

図 6 相分離変換法によるリグノクレゾール生成模式図 
表 7 リグノクレゾールのエポキシ化条件とエポキシ樹脂の性状

\begin{tabular}{|c|c|c|c|}
\hline & \multicolumn{2}{|c|}{ Osaka Municipal Technical Research Institute } & Yokohama National Univ. \\
\hline \multicolumn{4}{|c|}{ 1, Material \& Reaction condition } \\
\hline Lignophenol (LP) & $\begin{array}{l}\text { Lignocresol } \\
\left(M_{\mathrm{w}}=11400\right)\end{array}$ & $\begin{array}{l}\text { Lignocresol } \\
\left(M_{\mathrm{w}}=4700\right)\end{array}$ & $\begin{array}{l}\text { Lignocresol } \\
\left(M_{\mathrm{n}}=5300\right)\end{array}$ \\
\hline $\mathrm{LP} / \mathrm{ECH}^{\text {a) }}$ molar ratio & \multicolumn{2}{|c|}{$1 / 20$} & $1 / 20$ \\
\hline Phase-transfer cat. & \multicolumn{2}{|c|}{ (Not used) } & $\mathrm{TBAB}^{\mathrm{b})}$ \\
\hline $\mathrm{NaOH}$ & \multicolumn{2}{|c|}{$20 \% \mathrm{NaOH}$} & $50 \% \mathrm{NaOH}$ \\
\hline Reaction condition & \multicolumn{2}{|c|}{$55-60^{\circ} \mathrm{C} / 2 \mathrm{~h}$} & $\begin{array}{l}80^{\circ} \mathrm{C} / 4 \mathrm{~h} \text { for phase-transfer } \\
<10^{\circ} \mathrm{C} / 10 \mathrm{~h} \text { for ring closure }\end{array}$ \\
\hline \multicolumn{4}{|l|}{ 2, Property of epoxy resin } \\
\hline Appearance & Brown solid & Brown solid & Solid \\
\hline Epoxy equivalent & $782 \mathrm{~g} / \mathrm{eq}$ & $745 \mathrm{~g} / \mathrm{eq}$ & $230-250 \mathrm{~g} / \mathrm{eq}$ \\
\hline$M_{\mathrm{w}}$ & 7720 & 2600 & (Not available) \\
\hline$M_{n}$ & $\begin{array}{c}2390 \\
\left(M_{\mathrm{w}} / M_{\mathrm{n}}=3.23\right)\end{array}$ & $\begin{array}{c}1625 \\
\left(M_{\mathrm{w}} / M_{\mathrm{n}}=1.60\right)\end{array}$ & $7000-7500$ \\
\hline Epoxidation ratio & $39 \%$ & $42 \%$ & ca. $100 \%$ (estimated) \\
\hline
\end{tabular}

a) Epiclorohydrine, b) Tetrabuthylammonium bromide

使用した場合は木材の種類による収率にほとんど差は無く, その $M_{\mathrm{w}}$ は針葉樹系素材で $5,000 \sim 10,000$, 広葉樹系素材 で 3,000〜 5,000 となっている。そして，このリグノクレ ゾールはアルカリ等で処理することで， 2 量体レベルまで 低分子化が可能であり，さらに，単量体化やメトキシ基の 脱メチル化により, 木材由来のモノフェノール誘導体（グ アイアコール, カテコール, クレゾール）へ到達できるこ とも確認されている。

リグノクレゾールのエポキシ樹脂としての利用は, 大阪 市工研 ${ }^{49,50)}$ や, 横浜国立大学 ${ }^{51,52)}$ を中心とするグループ により試みられている。表 7 にリグノクレゾールの主なエ ポキシ化条件とエポキシ化リグノクレゾールの性状を示す。 リグノクレゾールは通常のエポキシ化条件 $\left(120^{\circ} \mathrm{C}\right)$ では アルカリにより分解してしまうため, 比較的低い温度条件 で反応を行い, さらに $\mathrm{NaOH}$ と相間移動触媒を用いる 2 段エポキシ化反応手法もとられている。表 7 に示すよう に,このエポキシ化リグノクレゾール樹脂は比較的分子 量が大きく室温では固形であるため, 門多ら ${ }^{49,50)}$ や津田 ら ${ }^{51,52)}$ は, 液状のビスフェノール A 型エポキシ樹脂 (DGEBA) や脂環型エポキシ樹脂 (ECEC) とブレンドし 特性評価を行っている。その結果, リグノクレゾールの剛 直な骨格により耐熱性の向上や接着特性の向上が確認され ている。一方, リグノクレゾールをエポキシ樹脂の硬化剂 として利用する試みむなされていて, 津田ら ${ }^{51)}$ は, ビス フェノール A 型エポキシ樹脂をイミダゾール誘導体を触 媒としてリグノクレゾールにより硬化し, バイオマス由来 成分含有量最大 $49 \%$ が可能で, 耐熱性の向上を確認して いる。さらに，エポキシ化リグノクレゾールと DGEBA
や ECEC とブレンドし，リグノクレゾールで硬化させた 硬化物は，バイオマス由来成分含有量最大 $82 \%$ となり， $T_{\mathrm{g}}$ が $200^{\circ} \mathrm{C}$ を超え熱重量分析においても熱的に安定した值 を示した ${ }^{52)}$ 。しかし，機械的特性の点ではリグノクレゾー ルの含有量が多くなるに従い，エポキシ樹脂の剛直性が増 し曲げ強度が低下するとの結果が得られている。

また，相分離変換法によるリグノフェノールの工業的生 産についても, 開発者である舩岡らにより検討されていて, 小規模生産プラントを建設・稼動済みであり，実用化も近 い段階に来ていると考えられている ${ }^{47,48)}$ 。そしてエポキ シ化リグノフェノール樹脂の工業的な利用については, 電 気絶縁材料（特許第 3936214 号），接着材料（特開 2004210816), 銅張り積層板および樹脂封止材（特開 2009292884, 特開 2010-150298）などの用途向け組成物特許か 数報出願されている。その他, エポキシ樹脂システムとし ては特殊であるが, リグノフェノールをカルボキシアルキ ル化し, PEGDGEやポリプロピレングリコールジグリシ ジルェーテルなどの水溶性エポキシ樹脂で架橋するという 吸水性材料の特許（特許第 4015035 号）屯ある。

3.2.6 木材をアルカリ等で分解して得られた低分子リグ ニン化合物を, 細菌 (Sphingomonas paucimobilis SYK -6株）によりいくつかの経路を経て分解させ，最終的に 均一な一つの化合物, 2-pyron-4,6-dicarboxylic acid （PDC）に到達する。得られた PDC を精製した後，エポ キシ化してグリシジルェステル型エポキシ樹脂を得る方法

(表 4-O, 表 6-O)。

Sphingomonas paucimobilis SYK-6 株（以下 SYK-6 株）は片山らによりパルプ廃液処理槽から単離され，リグ 


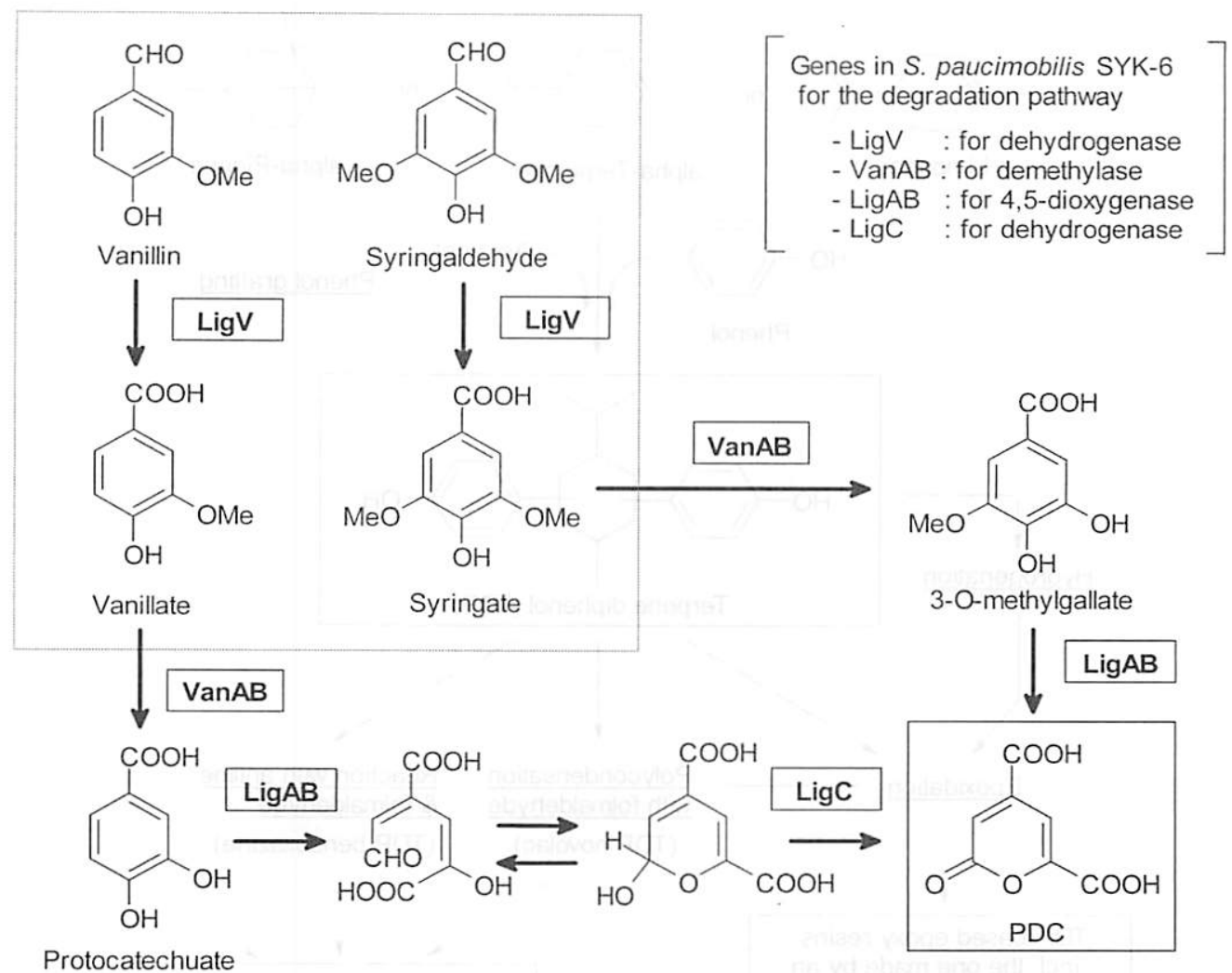

図 7 Sphingomonas paucimobilis SYK-6 株による低分子リグニンから PDCへの代謝経路

ニン 2 量体化合物を含む低分子リグニン類を多様で特異的 な酵素系によって代謝できることが確認されている ${ }^{53 \sim 56)}$ 。 このSYK-6 株により低分子リグニン化合物をことごとく 分解し PDC に至る画期的な生成ルートが確立され, PDC を高分子量化しポリマーを得る応用展開の一環としてェポ キシ樹脂への利用法も開発されている。低分子リグニン化 合物の代表例は, バニリン, バニリン酸, シリンガアルデ ヒド，シリンガ酸，などであるが，木材に限らず他の植物 バイオマスからあ得ることは可能である。これらの低分子 リグニンから PDC に至る代謝経路の中で, 表 6-Oのフ ローに関連する部分のみを示すと図 7 のよおりなる。こ の代謝経路に関与する SYK-6 株の遺伝子は片山ら ${ }^{57,58)}$ や政井ら ${ }^{59 \sim 62)}$ により詳細に解析され, さらにPDC から 先の二酸化炭素, 水への分解経路も確認されている。そし て, SYK-6 株に由来する組換え細菌を用い, 150 リッター の発酵槽でバニリンなどの低分子リグニンから効率的に PDC を生産する「遺伝子組換えバイオリアクター」を構 築済みである ${ }^{53)}$ 。このバイオリアクターで得られる PDC は, 通常の化学的な合成が非常に難しいだけでなく, 分子 構造内に異方性を持ち電子の偏りがあるため, 物理化学的 特性の面であ注目されている特異な物質であり, 高分子化 することで，ポリエステル，ポリアミド，ポリウレタンな どへの応用展開が図られている63)。

$\mathrm{PDC}$ をエポキシ樹脂として利用する手法としては, ECH を用いる一般的なエポキシ化法とは別に, 論文 ${ }^{64)}$ や公開
特許（特開 2010-59095）に次の 2つの手法が提案されて いる。(1)グリシドールを用いて，テトラヒドロフラン (THF) 中で低温 $\left(0 \sim 5^{\circ} \mathrm{C}\right)$ にてエポキシ化する方法, (2) $\mathrm{PDC}$ とアリルアルコールなどの不飽和アルコールを酸触 媒存在下で脱水反応させた後, 末端二重結合を酸化してエ ポキシ化する方法。こうして得られた PDC ジグリシジル エステルは, 無水マレイン酸や無水フタル酸を硬化剂とし て用いた場合，ステンレス板や鉄板との引張り接着強度は ピスフェノール A 型エポキシ樹脂より大幅に向上してい ることが確認されている。この高い接着強度のメカニズム についての推論もなされていて, 金属の極性表面と PDC の $\alpha$-ピロン環開裂により生じた極性基との相互作用に起 因すると考えられている ${ }^{64)}$ 。

\section{3 リグニン以外の木質素材ベースエポキシ樹脂シス テム}

木質バイオマスのエポキシ樹脂への利用法として, リグ ニン以外にセルロースやへミセルロースなどを利用する方 法もあるが, 実用性という観点から木質バイオマスから分 離・精製された材料として, (1)テルペン化合物と(2)天然ゴ ム, のエポキシ樹脂システムへの利用について述べてみた い。

3.3.1 テルペン化合物は, 主にオレンジ果皮や松ヤ二, 松科の樹木などから得ることができるイソプレンを構成単 位とする炭化水素であり, 構造によって非環式, 単環式, 


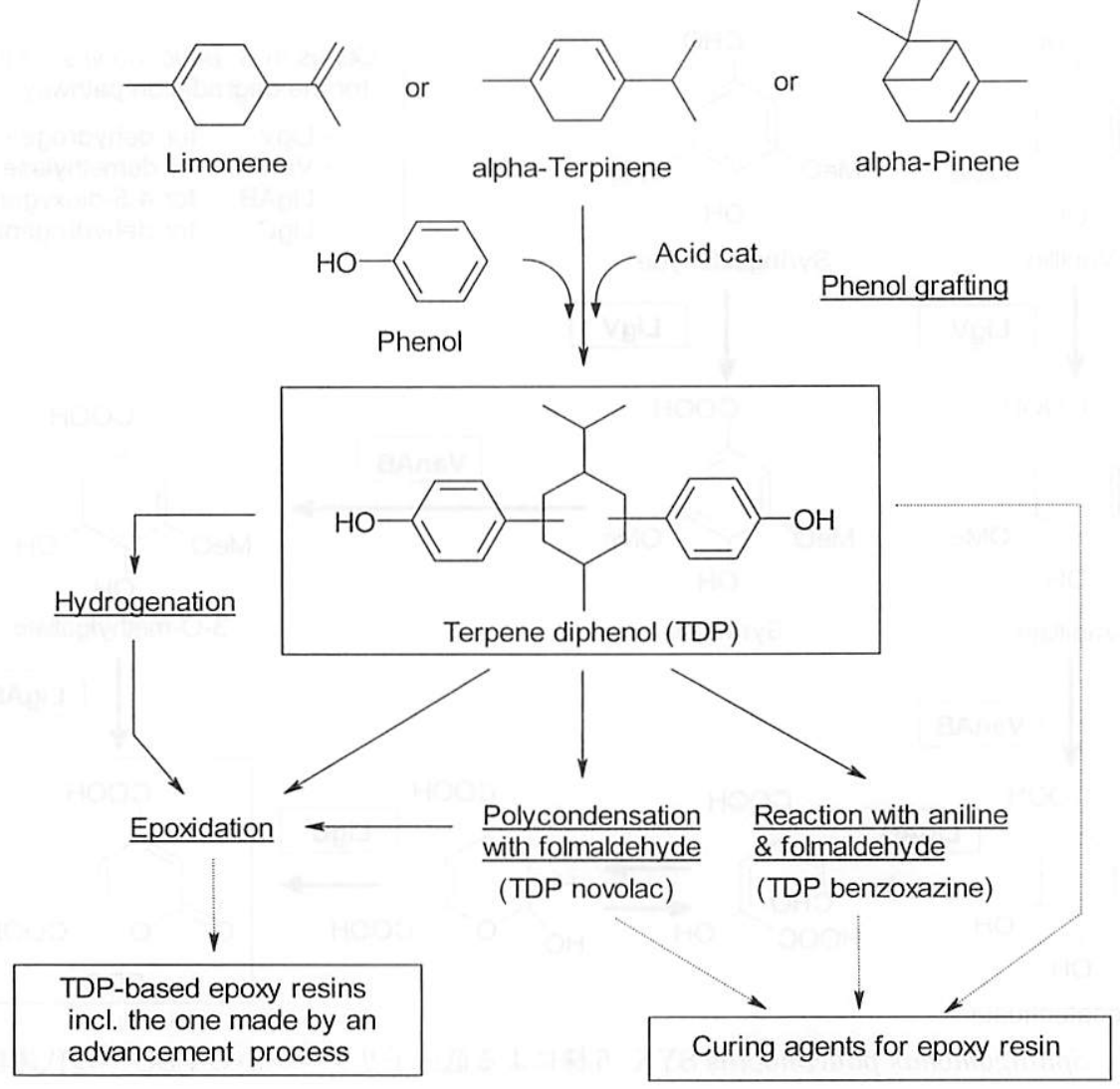

図 8 テルペンジフェノールの合成とエポキシ樹脂システムとしての利用

二環式，三環式に分類することができる。その中で，単環 式テルペン化合物としては, リモネン, ジペンテン（リモ ネンの光学異性体), テルピノーレン, $\alpha$-ピネン, $\beta$-ピ ネン, テルピネン, メンタジェンなどがあり, これらはエ ポキシ樹脂や硬化剤の原料として利用されている。その代 表例には,リモネンの二重結合を酸化したジェポキシリモ ネンがあり, 反応性希釈剤や光カチオン硬化に利用されて いる。その他の例としては, テルペン類にフェノールを付 加したテルペンジフェノール (TDP) がある（特開平 8198791)。図 8 に TDP の合成法とエポキシ樹脂システム としての利用法を, 簡略化したフローで示してある ${ }^{65 ~ 67) 。 ~}$ フローに示すエポキシ樹脂システム用素材の中で, TDP 以外で実際に商品として流通した実績のあるものは, (1)液 状のビスフェノール型 2 官能エポキシ樹脂に， 2 段法 (Advancement process) により TDP を反応させた溶剂 型塗料用エポキシ樹脂（特許第 3508033 号）と, (2)TDP とホルマリンを重縮合させ, 半導体封止用硬化剤として利 用した TDPーノボラック樹脂（特許第 2876304 号, 特許 第 2572293 号), がある。

もう一つの環状テルペン類の利用例としては, $\alpha$-ピネ ンや $\beta$-ピネンの熱異性化により得られるアロオシメンに 無水マレイン酸を付加したマレイン化アロオシメンがある (図 9 の合成法参照)。このマレイン化アロオシメンは室温

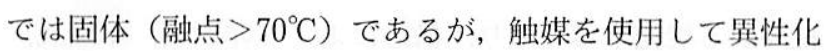

することで室温で安定的に液状となる（特公昭 62-5151）。 そして, 芳香族環のアルキル置換基の寄与により耐水性を 向上した電気注型用酸無水物系硬化剤として多くの実績が ある7,68)。

3.3 .2 天然ゴムはバラゴムノキ（Hevea brasiliensis） の樹液に含まれる cisーポリイソプレン $\left[\left(\mathrm{C}_{5} \mathrm{H}_{8}\right)_{\mathrm{n}}\right]$ を主成 分とする木質由来の高分子で，松ヤ二同様いわゆる「樹脂」 であり，その主たる用途は夕イヤである。タイヤを構成す る数多くの素材の中で, 天然ゴムなどの石油外材料の比率 は標準的な夕イヤの場合約 $44 \%$ と言われている。脱石化 原料の観点からタイヤ構成成分の石油外素材比率を上げる ため, 天然ゴムを過䣫酸などで二重結合を酸化したエポキ シ化天然ゴム（ENR）が合成ゴムの代替として用いられ， 「97\%石油外天然資源タイヤ」と銘打ったタイヤも商品化 されている。しかし, この場合, タイヤ用 ENR は加硫剂 により架橋され, エポキシ基はウエットグリップ性能や龟 裂防止などの特性改良用の置換基としての機能を担ってい るものである ${ }^{69)}$ 。

一方, ENR 中のエポキシ基をポリアミン類や酸無水物 類などの硬化剤で架橋し, 接着剤（特公平 07-047723, 特 許第 2987391 号) や制振材（特開平 06-220303, 特許第 3059838 号）などへ適用する試みもなされている。一般に, 天然ゴムには少量の蛋白質や脂質等の非ゴム成分が含まれ， 特に, 蛋白質は化学反応における副反応の原因やラテック 


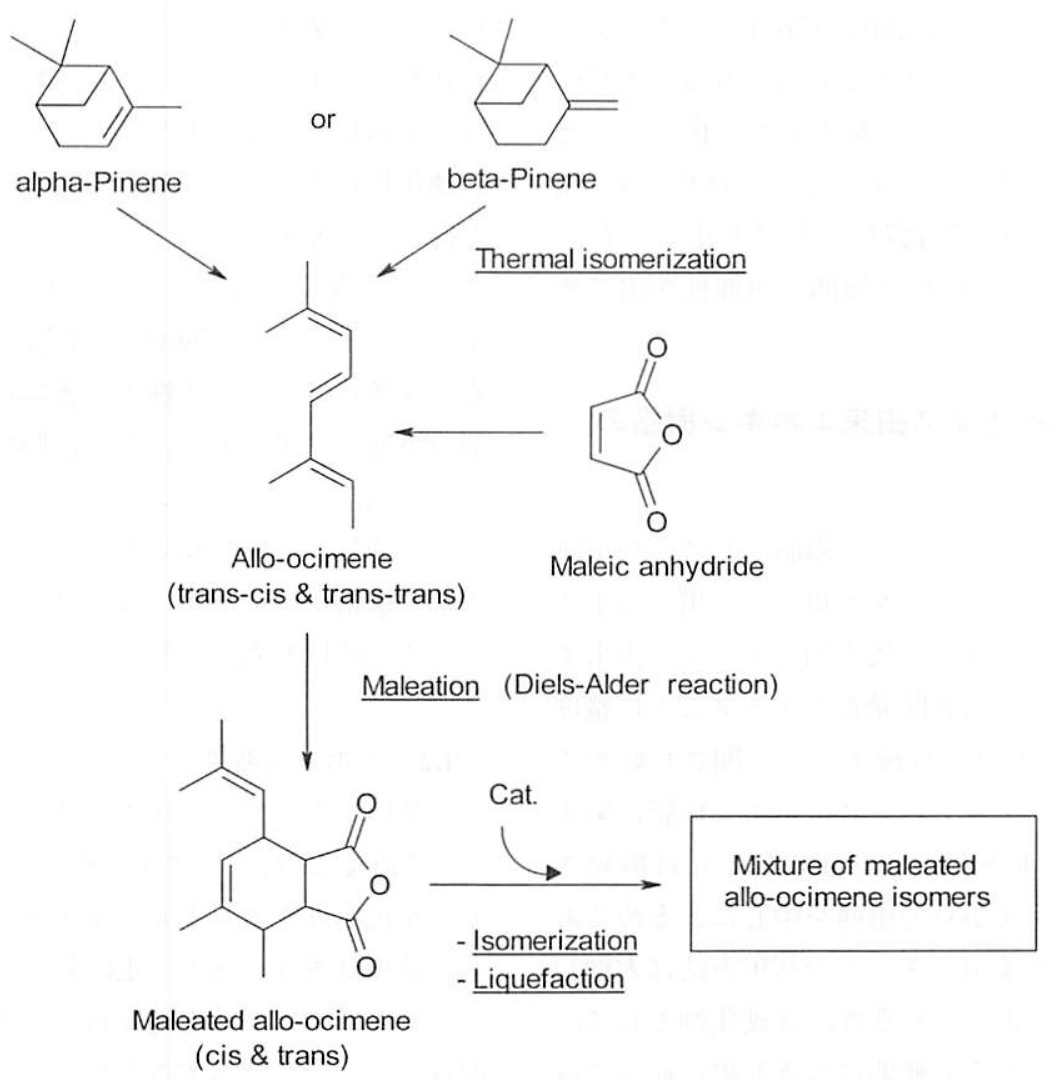

図 9 環状テルペン化合物からのマレイン化アロオシメンの合成法

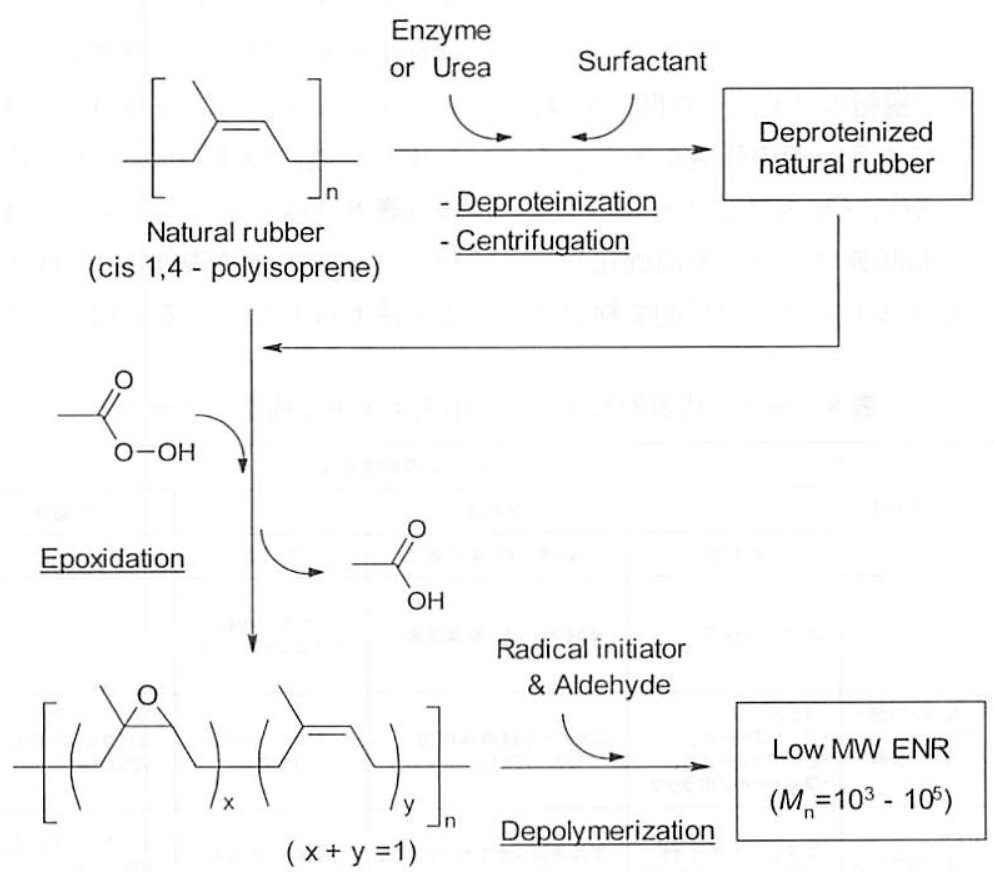

Epoxidized natural rubber (ENR)

図 10 天然ゴムのエポキシ化変性法

スアレルギーの原因となり，天然ゴムを合成ゴムの代替と して幅広く適用するための障害となっていた。図 10 に天 然ゴムから ENRへの変性ルートを示すが, 天然ゴムを(1) 酵素（特許第 2905005 号, 特許第 4102499 号) や, (2)尿素 系化合物など（特許第 3581866 号), を用いて変性後, 洗
浄や複数回遠心分離などの分離手法で蛋白質をほとんど除 く（窒素含有率 $00.02 \mathrm{wt} \%$ ）技術が開発され，それを用 いた ENR む利用可能となっている。さらに, ラジカル開 始剤とアルデヒドで酸化分解することで，ENRの数平均 分子量を $10^{3} \sim 10^{5}$ 程度にまで低下させ, 液状化するこよ 
あ可能になってきている（特開 2004-176013）。このよう に様々な技術開発により,ゴムノキから得ら机る「天然の 樹脂」由来の cisーポリイソプレンをエポキシ化すること で，エポキシ樹脂としてばかりでなく他の高分子の合成用 や変性用素材（特開 2009-173727）としても用いられ， 「グリーンポリマー」として幅広い展開の可能性が出てき ている。

\section{4. 海外での木質バイオマス由来エポキシ樹脂の 開発}

海外での木質バイオマスのエポキシ樹脂としての利用研 究は, 基本的には工業用リグニンを原料として用いる手法 が取られている。表 8 に海外での代表的なりグニン由来エ ポキシ樹脂システムの開発例を開発者グループごとに整理 してみた。技術論文は 1980 年代後半から公開され始めて いるが，これ以前にもリグニンベースエポキシ樹脂に関す る特許（1975 年出願, U.S.P. 3,984,393 など）は散見さ れる。しかし, 表には論文からの出典を中心にまとめてあ る。表に示すように, 工業用リグニンの利用方法は大別し て, (1)単純ブレンド, (2)エポキシ変性, (3)硬化剂としての 利用，となり，以下，これらの概要につき簡単に述へてみ たい。

\section{1 単純ブレンド}

クラフトリグニンとエポキシ樹脂のブレンドに関しては, Feldman ら ${ }^{70 ~ 76)}$ のグループによる一連の研究がある。こ の場合, リグニンとエポキシ樹脂（ビスフェノール A 型） を意図して反応はさせずに，脂肪族アミン（室温硬化）と 組み合わせ，接着剤用としてコストダウンの目的で検討さ
れている(表 8-P)。リグニンの硬化物の $T_{\mathrm{g}}$ とせん断接 着強度（アルミ）に関して得られた主な結果をまとめると 以下の通りとなる。(1)リグニンをブレンドしたエポキシ樹 脂硬化物はリグニン添加量 $20 \mathrm{wt} \%$ までは均一で単一の $T_{\mathrm{g}}$ を持つが, $25 \mathrm{wt} \%$ 以上では二つの $T_{\mathrm{g}}$ ピークをむつ, (2)リ グニンを $30 \mathrm{wt} \%$ までの添加で接着強度は比較エポキシ樹 脂より向上し, 約 $20 \mathrm{wt} \%$ の添加で接着強度はピークとな る。(3)接着特性と耐久性の改善には, シランカップリング 剤の添加は効果がある。なお, 脂肪族アミンを用い室温硬 化した場合は, リグニンはエポキシとアミンの反応にはほ とんよ゙関与しないと見られるが，加熱硬化した場合は，エ ポキシ樹脂と反応せずに残ったアミンがリグニンと結合し ている可能性む考えられている。

\section{2 エポキシ変性}

工業用リグニンのエポキシ变性は大別して, (1)各種リグ ニンを直接 $\mathrm{ECH}$ でエポキシ化する方法と, (2)前处理（フェ ノール化処理やアルキレンオキサイド付加）を行ってリグ ニン誘導体を生成後に, ECH でエポキシ化する方法, が ある。ここでは, 前処理を行った後にエポキシ化する例を 取り上げ，少し述べてみたい。

4.2.1 Simionescu ら ${ }^{77 \sim 81)}$ のグループは，リグニンス ルフォン酸ーアンモニウムやリグニンスルフォン酸ー鉄を 含有する亜硫酸パルプ廃液を，フェノール誘導体類（フェ ノール，ビスフェノール A，ノボラックなど）でフェノー ル化した後, ECHでエポキシ化しエポキシ樹脂を得てい る（表 8-Q）。なお，フェノール誘導体を添加しない方法 や,フェノール誘導体と ECH と同時に添加し, 反応させ る方法も行われている。得られたエポキシ化リグニンスル

表 8 海外の代表的なりグニン由来エポキシ樹脂システム

\begin{tabular}{|c|c|c|c|c|c|c|c|c|c|c|}
\hline \multirow{3}{*}{ 分類 } & \multirow{3}{*}{\multicolumn{2}{|c|}{ 研究者グループ }} & \multirow{3}{*}{ 原料リグニン㮩導体 } & \multicolumn{4}{|c|}{ リグニンの処理方法 } & \multirow{3}{*}{ 架橋剂の例 } & \multirow{3}{*}{$\begin{array}{l}\text { エポキシ } \\
\text { 関連文献 } \\
\text { 公開年代 }\end{array}$} & \multirow{3}{*}{ 文献 } \\
\hline & & & & \multicolumn{3}{|c|}{ 一次処理 } & \multirow{2}{*}{$\frac{\text { 二次処理 }}{\text { 処理剂 }}$} & & & \\
\hline & & & & 処理剤 & 処理内容 (条件等) & 生成物 & & & & \\
\hline $\begin{array}{l}\text { ブ } \\
\stackrel{2}{\text { L }} \\
\text { ト }\end{array}$ & $P$ & D.Feldman ら́ & ·クラフトリグニン & •エポキシ樹脂 & ·単純ブレンド(室温混合) & $\begin{array}{l}\text { エポキジ樹脂/ } \\
\text { リグニン・ブレンド }\end{array}$ & - & 脂肪族アミン & $1988 \sim$ & $70 \sim 76$ \\
\hline \multirow{4}{*}{$\begin{array}{l}I \\
\text { 足 } \\
\neq \\
\vdots \\
\text { 変 } \\
\text { 性 }\end{array}$} & Q & $\begin{array}{l}\text { C.I. Simionescu, } \\
\text { C. Vasilら̌ }\end{array}$ & $\begin{array}{l}\text { ・リグニンスルフォン酸- } \\
\text { アンモニウム } \\
\text {-リグニンスルフォン酸- } \\
\text { 鉄 }\end{array}$ & 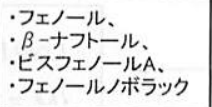 & 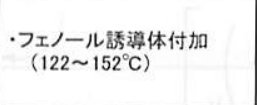 & $\begin{array}{l}\text { フェノール化 } \\
\text { リグニン }\end{array}$ & $\begin{array}{l}\cdot \text { エヒピクロルヒドリン } \\
\cdot 35 \% \mathrm{NaOH}\end{array}$ & $\begin{array}{l}\text { 芳香族アミン } \\
\text { 酸無水物 }\end{array}$ & $1987 \sim$ & $77 \sim 81$ \\
\hline & $\mathrm{R}$ & $\begin{array}{l}\text { K. Hofmann, } \\
\text { W.G. Glasser }\end{array}$ & 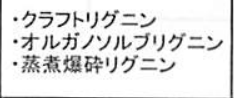 & $\begin{array}{l}\text { ·エチレンオキサイド } \\
\text { ·プロピレンオキサイト }\end{array}$ & $\begin{array}{c}\text { ·アルキレンオキサイド付加 } \\
\text { (140ㄷ } \mathrm{C} \text { inトルエン) }\end{array}$ & $\begin{array}{l}\text { 末端OH惁含有 } \\
\text { リグニン }\end{array}$ & $\begin{array}{l}\text { ·エピクロルヒドリン } \\
\text { ·固形KOH } \\
\text { ·級アンモニウム㙁 }\end{array}$ & 芳香族アミン & $1989 \sim$ & $91 \sim 94$ \\
\hline & $\mathrm{s}$ & B. Zhaoら & $\begin{array}{l}\text { ・リグニンスルフォン酸 } \\
\text { カルシウム }\end{array}$ & 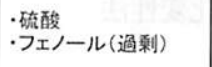 & $\begin{array}{l}\text {-1リグニンのフェノール化 } \\
\left(95^{\circ} \mathrm{C}\right)\end{array}$ & $\begin{array}{l}\text { フェノール化 } \\
\text { リグニン }\end{array}$ & $\begin{array}{l}\cdot \text { エピクロルヒドリン } \\
\cdot 20 \% \mathrm{NaOH}\end{array}$ & $\begin{array}{l}\text { 酸無水物 } \\
\text { イミダゾール }\end{array}$ & $2001 \sim$ & $95 \sim 97$ \\
\hline & $T$ & $\begin{array}{l}\text { T. Malutan, } \\
\text { V.1. Popaら }\end{array}$ & $\begin{array}{l}\text { ·アルカリリグニン } \\
\text { ·ヒドロキシメチル化 } \\
\text { リグニン }\end{array}$ & $\begin{array}{l}\cdot \text {-エピクロルヒドリン } \\
\cdot 208 \mathrm{NaOH} \\
\cdot 20 \mathrm{NaH}_{2} \mathrm{PO}_{4}\end{array}$ & $\begin{array}{l}\text { ・リグニンのエポキシ化 } \\
\left(50 \sim 90^{\circ} \mathrm{C}\right)\end{array}$ & $\begin{array}{l}\text { エポキシ化 } \\
\text { リグニン }\end{array}$ & - & - & $2008 \sim$ & 98 \\
\hline $\begin{array}{l}\text { 硬 } \\
\text { 华 } \\
\text { 剂 }\end{array}$ & $u$ & L. Kosbarī & $\begin{array}{l}\cdot \text { ·ララフトリグニン } \\
\text { (酸洗浄後使用) } \\
\cdot \text { オルガリルブニン }\end{array}$ & $\begin{array}{l}\text { ·エポキシ樹脂 } \\
\text { ·ガラスクロス }\end{array}$ & $\begin{array}{l}\text { ·積㕠板のプレス成形 } \\
\text { (リグニンは硬化剂) }\end{array}$ & $\begin{array}{c}\text { ガラスクロス皘層板 } \\
\text { (リグニン含有量 } \\
\text { :25 67\%) }\end{array}$ & - & - & $1996 \sim$ & 99. 100 \\
\hline
\end{tabular}


フォン酸は, 通常二成分からなり, 一つは茶褐色液状で水 に一部溶解し，もう一つは，水に不溶な黄褐色の高分子固 形樹脂である。

これらのエポキシ化リグニンスルフォン酸は, 単独又は ビスフェノール A 型エポキシ樹脂とブレンドして特性評 価され，硬化物は均一な構造で注型もフィルム成形も可能 であり, 誘電特性や力学的特性に優れることが判明してい る。しかし, その後, リグニンスルフォン酸-アンモニウ ムベースのエポキシ樹脂については, 架橋して硬化物とし て利用するのではなく, Cazacuらのグループにより, ポリ オレフィン（ポリエチレン, ポリプロピレン, ポリエチレ ンテレフタレートなど）にブレンドすることで，土壤中で の生分解性を付与する方向に研究が進められている ${ }^{82 \sim 89) 。}$ また，エポキシ化リグニンスルフォン酸の機能向上手法と して, リン含有ジオールを反応させることで, 熱安定性と 難燃性を付与したエポキシ化合物を得る試みむなされてい $3^{90)}$ 。

4.2.2 Glasser ら ${ }^{91 \sim 94)}$ のグループは, リグニンとアル キレンオキサイドを反応させた後に $\mathrm{ECH}$ と反応させてエ ポキシ化リグニン樹脂を得ている（表 8-R）。一般的には, まずプロピレンオキサイド（PO）を何モルか付加して鎖 を延長し溶剂溶解性を向上させた後, エチレンオキサイド （EO）でエンドキャップして一級の水酸基を末端に残す形 が好ましい。EO, PO はリグニン中のフェノール性水酸 基にもアルコール性水酸基にも付加するが, 一例として, フェノール性水酸基に $\mathrm{EO}, \mathrm{PO}$ を付加した後にエポキシ 化する反応の模式図を図 11 に示す。具体的には, リグ二 ンとしてオルガノソルブリグニン, 蒸煮爆砕リグニンを用 い, 様々なモル量の $\mathrm{PO}$ と $\mathrm{EO}$ を付加して得られたエポキ シ化リグニン樹脂は, 分子量が 1000 から 30000 , エポキ シ当量が 200 から $700 \mathrm{~g} / \mathrm{eq}$ であった。このエポキシ化リ
グニン樹脂をメタフェニレンジアミン（mPDA）で硬化 し, 注型物とフィルム形状で $T_{g}$ と引張り特性が評価した ところ, 市販の液状ビスフェノール A 型エポキシ樹脂 (Epon 826) と比較し, 分子量にあ依存するが, 引っ張り 特性に優れていることが確認されている。

4.2.3 Zhao ら 95 97) のグループは, 以下の手法でエポ キシ化リグニン樹脂を得ている（表 8-S)。(1)リグニンス ルフォン酸カルシウムに硫酸と過剩のフェノールを加え, $95^{\circ} \mathrm{C}$ で 3 時間反応させて 2 相（有機相と水相）に分かれる 生成物を得る。(2)有機相を中和後, フェノールを蒸留除去

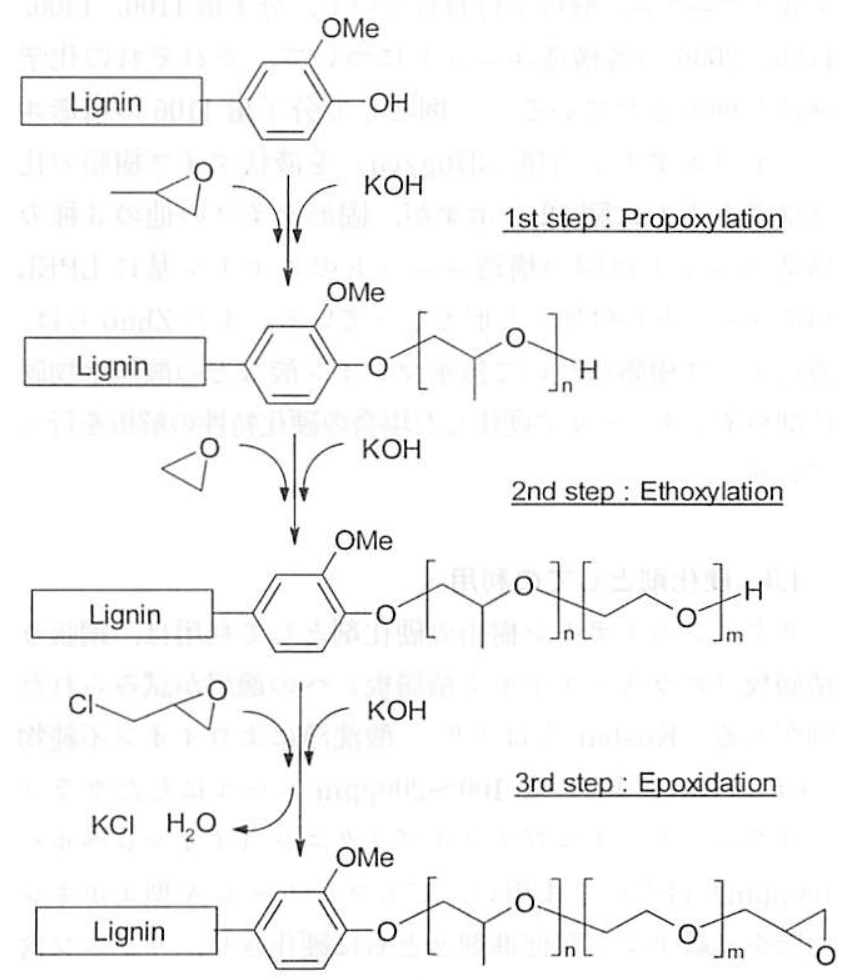

図 11 リグニンのアルキレンオキサイド付加と エポキシ化模式図<smiles>OCCC(c1ccc(OCC2CO2)cc1)c1ccc(OCC2CO2)cc1</smiles><smiles>COc1cc(C(CCO)c2ccc(OCC3CO3)cc2)ccc1OC(CO)C(O)c1ccc(OC(CO)C(c2ccc(OCC3CO3)cc2)c2ccc(OC(CO)C(O)c3ccc(OCC4CO4)cc3)c(OC)c2)c(OC)c1</smiles>

図 12 リグニンスルフォン酸ベースエポキシ樹脂の代表的な化学構造 
し黒色ゲル状物（PLS）を得る。PLS は水に一部可溶で あり，水可溶成分（PLS1）上水不溶成分（PLS2）に分 離可能である。(3)の PLS2 に ECH と $20 \% \mathrm{NaOH}$ 溶液 を加え反応させることで，暗赤褐色の液状エポキシ樹脂 (LEPL) と黄色の固形エポキシ樹脂 (LEPS) が得られ, 両者とあ水に不溶である。

液状タイプのエポキシ化リグニンスルフォン酸の分子量

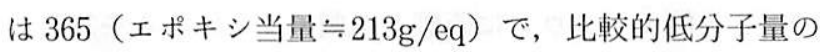
あのが得られている (図 12 参照)。固形タイプ樹脂（エポ キシ当量 $=588 \mathrm{~g} / \mathrm{eq})$ についてむ, 化学構造の推定および 生成メカニズムの解析が行われていて, 分子量 1106, 1406, 1706, 2006 の各構造ユニットについて, それぞれの化学 構造が例示されている。一例として分子量 1106 の構造ユ ニット（エポキシ当量 $\fallingdotseq 370 \mathrm{~g} / \mathrm{eq} ）$ を液状タイプ樹脂の化 学構造ととむに図 12 に示すが, 固形夕イプの他の 3 種の 構造ユニットは図の構造ユニットのエポキシ基に LPEL 構造ユニットが付加した形となっている。またZhaoらは, 液状夕イプ樹脂について無水マレイン酸などの酸無水物硬 化剂やイミダゾールで硬化した場合の硬化特性の解析を行っ ている。

\section{3 硬化剂としての利用}

リグニンのエポキシ樹脂の硬化剤として利用は，銅張り 積層板（ガラスーエポキシ積層板）への適用が試みられた 例がある。Kosbar らは ${ }^{99,100)}$, 酸洗浄によりイオン不純物 （主に, $\mathrm{Na}^{+}, \mathrm{K}^{+}$) を 100〜200ppm レベルにしたクラフ トリグニンと, オルガノソルブリグニン（イオンレベル $<$ $100 \mathrm{ppm})$ はそのまま用い, ビスフェノール A 型エポキシ 樹脂を三級アミン系促進剤ととむに硬化させ, リグニン含 有量が 25〜 67wt\%の硬化物を得ている（表 8-U)。これ らのエポキシ硬化物の $T_{\mathrm{g}}$ は $100 \sim 145^{\circ} \mathrm{C}$ で, その他の特性 も含め一般的な難燃積層板グレード “FR-4”規格にマッ チしている。また, リグニン含有量約 $60 \mathrm{wt} \%$ までは特性 良好で, それ以上の含有では特性の低下が見られるが，そ の場合でも低級積層板用途（“FR-1”や“CEM”）には適 用可能と考えられている。なお, 多官能エポキシ樹脂と組

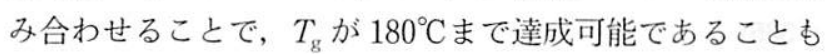
判明している。さらに実用途への適用を前提に, リグニン 含有量約 $50 \mathrm{wt} \%$ のパロットスケール樹脂配合の積層板 特性も評価され，ジシアンジアミド（DICY）硬化の一般 的な FR-4 タイプ積層板と同等以上の特性が確認され，特 許屯出されている (U.S.P. 5,833,883, U.S.P. 6,339,116)。 そして, エネルギー消費量の面では, 積層板生産に必要な 燃料を約 $40 \%$ 削減可能との試算も得られている。

\section{5. おわりに}

以上，木質バイオマスのエポキシ樹脂への利用研究につ
いて，主に技術文献を中心にして特許情報む交え，浅学を 省みずにまとめてみた。エポキシ樹脂への木質バイオマス の利用研究は, 世界的に見ても日本が最も進んでいるよう に思える。特に，木材からエポキシ樹脂の原料となる物質 を精製して得る技術に関しては，他に類を見ないユニーク な技術確立や実用化準備が進み, 世界を大きくリードして いると言っても過言ではない。これは, 将来を見据えた政 府管轄の各種研究推進支援による成果の現れ一つであると 思われる。天然資源が無いと言われる日本ではあるが, 再 生可能な木材資源は生態系のバランス（生物多様性）を崩 さない範讲で，いくらでも豊富に継続して得ることができ るあのである。

本格的な木質バイオマスベースのエポキシ樹脂の開発は まだ緒についたばかりであるが，従来からある植物油脂べー スエポキシ樹脂の高機能化技術の開発と相まって, 脱化石 資源による環境調和型・資源循環型社会の構築に向けて, 今後も更に開発が加速されていくであろう。そして, 地道 な開発努力の先には, 化石資源枯渇後もエポキシ樹脂が様々 な形で供給され続けていく姿が, 見えてくるものと思われ る。

\section{参 考 文 献}

32）富田文一郎, 農林水産省大型別枠研究バイオマス变換計画, 昭和 61 年度委託事業報告書「リグニン樹脂の開発」(1986).

33）中村堂利, 沢田達郎, 中本義章, ネットワークポリマー, 19, 26 (1998).

34) 中村嘉利, Cellul. Commun., 6, 85 (1999).

35）香川博之, 岡部義昭, 中澤ゆり, 榎本裕治, Material Stage, 10(7), 36 (2010).

36) M.Kobayashi, K.Tukamoto and B.Tomita, Holzforschung, 54, 93 (2000).

37) M. Kobayashi, Y. Hatano and B. Tomita, Holzforschung, 55, 667 (2001).

38) M. Kobayashi, T. Asano, M. Kajiyama and B. Tomita, $J$. Wood Sci., 51, 348 (2005).

39）小林正彦，木材工業，60, 202 (2005).

40) T. Asano, M. Kobayashi, B. Tomita and M. Kajiyama, Holzforschung, 61, 14 (2007).

41) 岸肇, 藤田晶, 宮崎光, 松田聡, 村上惊, 日本接着学会誌, 41, 344 (2005).

42) 藤田晶, 宮崎光, 松田聡, 岸肇, 村上惇, 日本接着学会誌, 42, 323 (2006).

43) H. Kishi, A. Fujita, H. Miyazaki, S. Matsuda and A. Mu rakami, J. Appl. Polym. Sci., 102, 2285 (2006).

44) H. Kishi and A. Fujita, Eng. Manage. J., 7, 517 (2008).

45）岸㢣，科学研究費補助金研究成果報告菖 (課題番号 : 19360307), 「植物由来架橋型ポリマーをバイオナノファイバーで強化す るバイオマスナノコンポジット」(2009).

46) H.Kishi, Y.Akamatsu, M.Noguchi, A.Fujita, S.Matsuda and H. Nishida, J. Appl. Polym. Sci., 120, 745 (2011).

47）舩岡正光, 科学技術振興機構, CREST 研究終了報告者「植 物系分子素材の高度循環活用システム」(2004).

48）舩岡正光, 科学技術振興機構, SORST 研究終了報告苦「植 物系分子素材の逐次精密機能制御システム」(2009).

49）門多丈治, 長谷川喜一, 舩岡正光, ネットワークポリマー, 27, 118 (2006). 
50）門多丈治，日本接着学会誌，43, 20 (2007).

51）津田祥平, 中川佳織, 大山俊幸, 高橋昭婎, 閂部義昭, 香川 博之, 山田真治，風部洋治，ネットワークポリマー，31，75 (2010).

52）津田祥平, 大山俊幸, 高橋眧雄, 岡部義略, 香川博之, 山田 真治，岡部洋治，高分子論文集，67, 497 (2010)。

53）片山義博, 科学研究鿓補助金研究成果報告肯 (棵題番号 : 18 208027)，「生命科学と有機材料科学を基盤とした植物バイ オマス资源からの機能性高分子材料の創製」(2009).

54) Y. Katayama, S. Nishikawa, M. Nakamura, K. Yano, M. Yamasaki, N. Morohoshi, and T. Haraguchi, Mokuzai Gakkaishi, 33, 77 (1987).

55）大塚祐一郎, 中村雅哉, 大原誠資, 片山義博, 重原淳孝, 政 井英司, 福田雅夫，環境バイオテクノロジー学会誌，6,93 (2006).

56) E. Masai, Y.Katayama and M.Fukuda, Biosci.Biotechnol. Biochem. 71, 1 (2007).

57) Y. Noda, S. Nishikawa, K. Shiozuka, H. Kadokura, H. Nakajima, K. Yoda, Y. Katayama, N. Morohoshi, T. Haraguchi, and M. Yamasaki, J. Bacteriol., 172, 2704 (1990).

58) S. Nishikawa, T, Sonoki, T. Kasahara, T. Obi, S. Kubota, S. Kawai, N. Morohoshi and Y. Katayama, Appl. Environ. Microbiol., 64, 836 (1998).

59) E.Masai, K.Momose, H.Hara, S.Nishikawa, Y.Katayama and M. Fukuda, J. Bacteriol., 182, 6651 (2000).

60) E. Masai, M. Sasaki, Y. Minakawa, T. Abe, T. Sonoki, K. Miyauchi, Y. Katayama, and M. Fukuda, J. Bacteriol., 186, 2757 (2004).

61) D. Kasai, E. Masai, K. Miyauchi, Y. Katayama and M. Fukuda, J. Bacteriol., 186, 4951 (2004).

62) T. Abe, E. Masai, K. Miyauchi, Y. Katayama and M. Fukuda, J. Bacteriol., 187, 2030 (2005).

63）道信剛志，重原淳孝，未来材料，9(8), 36 (2009).

64) Y. Hasegawa, K. Shikinaka, Y. Katayama, S. Kajita, E. Masai, M. Nakamura, Y. Otsuka, S. Ohara and K. Shigehara, 䋐維学会誌, 65, 359 (2009).

65）張偉, 饭島孝雄, 福田和吉, 友井正男, ネットワークポリマー, 18, 59 (1997).

66）松本明博, 木村㤵, 長谷川喜一, 福田明徳, 比留井絹, 岡本 忠, 日本接着学会誌, 34, 66 (1998).

67) H. Kimura, Y. Murata, A. Matsumoto, K. Hasegawa, K. Ohtsuka, A.Fukuda, J. Appl. Polym. Sci., 74, 2266 (1999).

68）三浦希機，大沼吉信，ポリマーダイジェト， 54(6), 62 (2002).

69) 内田守, 科学と工業, 83, 96 (2009).

70) D.Feldman and D. Banu, J. Polym. Sci., 26, 973 (1988).

71) D. Feldman and M. Khoury, J. Adhesion Sci. Technol., 2, 107 (1988).

72) D. Feldman, D. Banu and M. Khoury, J. Appl. Polym. Sci., 37, 877 (1989)

73) J. Wang and D. Feldman, J. Adhesion Sci. Tehnol., 5, 565 (1991).

74) J. Wang, D. Banu and D. Feldman, J. Adhesion Sci. Technol., 6, 587 (1992).

75) D. Feldman, D. Banu, A. Natansohn and J. Wang, $J$. Appl. Polym. Sci., 42, 1537 (1991).
76) D.Feldman, D.Banu, M.Lacasse. J.Wang and C. Luchian, J. Macromol. Sci. Pure Applied Chem. A, 32, 1613 (1995).

77) C. I. Simionescu, G. Cazacu and M. M. Macovenau, Cell. Chem. Technol., 21, 525 (1987).

78) C. I. Simionescu, V. Rusan, G. Cazacu, M. M. Macoveanu, R. Lipsa and G. Stoica, Cell. Chem. Technol., 24, 397 (1990).

79) C. I. Simionescu, V. Rusan, M. M. Macoveanu, G. Cazacu, R. Lipsa, A. Stoleriu and A. Ioanid, Cell. Chem. Technol., 25, 355 (1991).

80) C. I. Simionescu, V. Rusan, K. I. Turta, S. A. Bobcova, M. M. Macoveanu, G. Cazacu and A. Stoleriu, Cell. Chem, Technol., 27, 627 (1993).

81) C. I. Simionescu, V. Rusan, M. M. Macoveanu, G. Cazacu, R. Lipsa, C. Vasile, A. Stoleriu and A. Ioanid, Compos. Sci. Technol., 48, 317 (1993).

82) C. Vasile, M. Downey, B. Wong, M. M. Macoveanu, M. Pascu, J. H. Choi, C. Sung and W. Baker, Cell. Chem. Technol., 32, 61 (1998).

83) G. E. Agafitei, M. C. Pascu, G. Cazacu, A. Stoleriu, N. P opa, R. Hogea and C. Vasile, Angew. Makromol. Chem., 267, 44 (1999).

84) G. Cazacu, M. C. Pascu, G. E. Agafitei and C. Vasile, Macromol. Mater. Eng., 283, 93 (2000).

85) M. Pascu, M. M. Macoveanu, C. Vasile, A. Ioanid and R. C. Oghina, Cell. Chem. Technol., 34, 399 (2000).

86) G. Cazacu, M. C. Pascu, L. Profire and C. Vasile, J. Environ. Prot. Ecol., 3, 242 (2002).

87) G. Cazacu, M. Mihaes, M. C. Pascu, L. Profire, A. L. Kowarskik and C. Vasile, Macromol. Mater. Eng., 289, 880 (2004).

88) G. Cazacu, M. C. Pascu, L. Profire, A. I. Kowarski, M. Mihaes and C. Vasile, Ind. Crop. Prod., 20, 261 (2004).

89) I. Mindreci, C. Vasile, M. Pascu and G. Cazacu, Rom. Journ. Phys., 50, 1163 (2005).

90) O. Petreus, G. Cazacu, A. M. Necula and D. Ciolacu, Cell. Chem. Technol., 42, 569 (2009).

91) W. L. S. Nieh and W. G. Glasser, ACS Sym. Ser., 397, 506 (1989).

92) K. Hofmann and W.G. Glasser, J. Wood Chem. Technol., 13, 73 (1993)

93) K.Hofmann and W.G.Glasser, J.Adhesion, 40, 229 (1993).

94) K. Hofmann and W. Glasser, Macromol. Chem. Physic., 195, 65 (1994).

95) B. Zhao, G. Chen, Y. Liu, K. Hu and R. Wu, J. Mater. Sci. Lett., 20, 859 (2001).

96) H. Sun, G. Sun, H. Lv, Y. Liu, B. Zhao, N. Zhu and K. Hu, J. Appl. Polym. Sci., 105, 2332 (2007).

97) G. Sun, H. Sun, Y. Liu, B. Zhao, N. Zhu and K. Hu, Polymer, 48, 330 (2007).

98) T. Malutan, R. Nicu and V. I. Popa, BioRes., 3, 1371 (2008).

99) L.L.Kosbar and J.Gelorme, Annu. Tech. Conf. Soc. Plast. Eng. (54th), 2, 1378 (1996).

100) L. L. Kosbar, J.D. Gelorme, R. M. Japp and W.T. Fotorny, J. Ind. Ecol., 4, 93 (2000). 